\title{
PROFILE: FIONA ROBERTSON
}

Fiona Robertson is the director of the Aberdeen/Aberdeenshire-based new music organisation, sound. sound supports composers, organises outreach and community work and runs the sound festival, Scotland's festival of new music. In 2004 Fiona was one of the founders of sound, along with Professor Pete Stollery of the

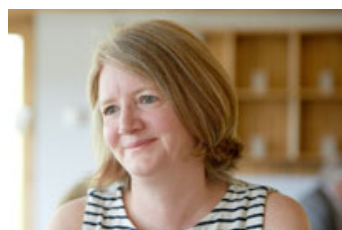

Fiona Robertson, photo Graeme MacDonald University of Aberdeen and Mark Hope of Woodend Barn, and since then she has worked to extend its scope, commissioning over 120 new works and promoting many more. Fiona has produced hundreds of events, brought many distinguished composers to Aberdeenshire, and nurtured a vibrant audience and community for new music in Scotland beyond the strongholds of Glasgow and Edinburgh. She was also instrumental in setting up New Music Scotland, bringing together promoters, composers and performers in Scotland.

On 28 February 2019 it was announced that Fiona is to be awarded the prestigious Leslie Boosey Award by the Royal Philharmonic Society. Presented every two years in recognition of those who work champion new music, the Leslie Boosey Award is not for composers or performers, but for programmers, publishers, broadcasters, administrators, educationalists and figures from the recording industry. James Murphy, Chief Executive of the Royal Philharmonic Society said of Fiona that 'she has made new music resound in an area where it may otherwise scarcely be heard'.

How did you come to be the director of sound?

Totally by chance! I didn't come up through the new music ranks: the only real experience I had of new music was playing Tuning by John McCabe when I was in the National Youth Orchestra of Scotland in 1985. I was brought up in Aberdeenshire, studied development economics and politics in Manchester (although I spent a lot of time in the music department playing viola) and ended up in Paris doing a post-grad degree in Arts Administration in 1990. I stayed in Paris, living and working there, partly in the arts world, partly for French NGOs, until 2003 when I came back to Aberdeenshire and started a part-time job in The Barn, a multi-arts centre in Banchory.

At the same time, Pete Stollery from the University of Aberdeen and Mark Hope from The Barn had been discussing setting up a new music festival in north-east Scotland and they came and asked if I'd like to be involved. I knew very little about contemporary classical music (I remember the first meeting where I noted most of the composers' names phonetically!) but was curious and loved the idea of setting up something new. And that's where the adventure began, setting up a pilot new music festival in 2004. You may wonder how someone who initially knew very little about new music could programme a festival, but sound has always been run in a very 
collaborative fashion with ideas coming from a range of people, which I bring together in what hopefully is a coherent festival programme. And after 15 years, my contemporary music knowledge has expanded exponentially.

Do you think of sound as a festival for the north-east of Scotland or as a new music festival that just happens to be in Aberdeenshire? What is the relationship between the festival and its audience?

I don't think sound festival would be the same if it happened anywhere else. It's very much rooted in north-east Scotland and was created in partnership with a number of local organisations in response to a particular local arts environment. When it was set up, there was little or no opportunity to hear new music in Aberdeen or Aberdeenshire - the orchestras didn't bring new works up to Aberdeen, and little else was going on. You had to travel to Glasgow or Edinburgh or further afield to hear anything news. That was the inspiration behind our programming policy: we try to put on as wide a variety of new music as possible so that audiences can discover what's out there.

We also decided right at the start to work in partnership with other arts organisations who have their own audiences. Our main aim is to bring new music to new audiences so rather than start from a blank sheet it seemed sensible to bring new music to existing music audiences. So, although we now programme and promote a majority of the concerts, many others are promoted by other organisations or co-promoted. This led us also to be fairly flexible in what could be promoted. For partner organisation programmes, we specified that each concert or event should include at least one piece of music by a living composer, but otherwise they could do what they liked. This allowed us to gently introduce some audiences to new music, while giving others the full-on new music experience they were looking for.

We also decided very early on to involve the local music community where possible. The first community event was bringing together a scratch orchestra of local musicians of all ages for a day to play James MacMillan's Into the Ferment, conducted by the composer. We now have our own new music ensemble, Any Enemy, which was set up in 2018 by local musicians and teachers, and we continue to organise one-off participative events, as well as singing days for the local community.

The arts community in Aberdeen is a very close-knit one, and we collaborate and support one another. This has led to a number of cross-art collaborations during the festival, including dance and new music with the DanceLive Festival and theatre and new music with Aberdeen Performing Arts. These events enrich our cultural landscape and allow us to bridge audiences. Our reality isn't only urban but also spans rural areas. Travelling around Aberdeenshire to remote village halls, some of which are literally in the middle of nowhere, can be a challenge for performers. But these intimate events are an integral part of what we do. Audiences can be significantly smaller in some cases, but the experience is very intense, and we believe it is important that new music is not only performed in urban spaces. At times when audiences seem small we work out a population multiplier, between whichever small community we're in and London, and quite often work out that we'd fill Wembley stadium over four times! 
As a relatively small festival, we're fairly close to our audiences and have got to know our loyal audience very well. We try to create an informal atmosphere where audiences feel comfortable chatting with the performers, composers and staff, and feel at ease in venues.

It is definitely different working in North East Scotland to working elsewhere. We're more remote than many parts of the UK: we feel distant from Glasgow and Edinburgh and even more so from London. Like many regional areas around the UK, there are distinct regional characteristics and realities. I believe that you have to adjust your offering to this reality to be successful. That's what we try to do at the sound, reacting to our local communities and engaging with them to bring together an annual new music festival.

What are your plans for the future of the festival?

Our plans are always to a large extent dependent on funding. New music events rarely, if ever, cover their costs. So it needs continued support from both public and private funders. We are currently facing cuts from Aberdeen City Council as it tries to make budgetary savings, which will affect our programme, but we hope to be able to adjust things slightly and carry on.

We will carry on our focus on endangered instruments, which has sparked our audience's curiosity. This year we'll be highlighting the oboe: the oboe community is already lining up to take part. More long term, we want to continue commissioning exiting new works, supporting composers and collaborating nationally and internationally as well as with our local arts community. And above all, we want to carry on exploring ways of increasing participation and finding new audiences to give more people from all walks of life the possibility of discovering the joy and excitement of creativity. 